\title{
POLSKI WYMIAR SPRAWIEDLIWOŚCI Z PUNKTU WIDZENIA EKONOMII INSTYTUCJONALNEJ*
}

\section{WPROWADZENIE}

Na wstępie wyjaśnię, że temat, o którym będzie mowa, należy do ekonomii instytucjonalnej ${ }^{1}$, czyli tej części nauk społecznych, która zajmuje się szeroko pojętymi instytucjami. Instytucje są też przedmiotem ekonomicznej analizy prawa (ang. law and economics), dziedziny, która powinien znać każdy ekonomista i każdy prawnik. Z ubolewaniem stwierdzam, że na studiach prawniczych w Polsce jest bardzo niewiele o tej dyscyplinie - wiele uwagi poświęca się przepisom, a mało ich sensowi w szerszej perspektywie - właśnie porząd$\mathrm{ku}$ instytucjonalnego. Na szczęście w Polsce są uruchamiane kierunki law and economics, czyli ekonomicznej analizy prawa. Ten kierunek pochodzi ze Stanów Zjednoczonych, gdzie sędziowie znają teorię ekonomii - nie orzekaja $\mathrm{w}$ ogóle w pewnych sprawach, jeśli nie sa zaawansowani w mikroekonomii, np. w sprawach antymonopolowych. Europa jest generalnie zapóźniona, jeżeli chodzi o rozwój ekonomicznej analizy prawa, a Polska jest zapóźniona w stosunku do Europy Zachodniej. Od kilku lat istnieje u nas Polskie Stowarzyszenie Ekonomicznej Analizy Prawa.

\section{SOCJALIZM JAKO USTRÓJ}

Ustrój można sobie wyobrazić jako zestaw trzech powiązanych członów:

1. Treść praw - używam słowa prawo tak jak jest zwykle używane przez prawników, tzn. mam na myśli przepisy, które egzekwuje państwo (tj. konstytucję, ustawy, rozporządzenia).

\footnotetext{
* Wykład wygłoszony na Wydziale Prawa i Administracji Uniwersytetu im. Adama Mickiewicza w Poznaniu 16 października 2012 r. Autor dziękuje Marcie Kube i Jarosławowi Bełdowskiemu za pomoc w przygotowaniu prezentacji przytoczonej w tym opracowaniu wykładu.

${ }^{1} \mathrm{Na}$ ten temat w RPEiS: M. Ratajczak, Transformacja ustrojowa $w$ świetle ustaleń i zatożeń ekonomii instytucjonalnej, „Ruch Prawniczy, Ekonomiczny i Socjologiczny” 2009, z. 2 (przyp. Redakcji).
} 
2. System typów organizacji - np. jaki jest udział przedsiębiorstw prywatnych w gospodarce, jaka jest struktura aparatu sprawiedliwości, jak wygląda system partyjny.

3. Mechanizmy masowych interakcji - ludzie wchodza w rozmaite interakcje, ale w jakie interakcje wchodza, zależy od poprzednich członów.

Jeżeli porządek prawny jest taki, że zakazuje własności prywatnej, tzn. będzie ona z mocy prawa przestępstwem (jak było w socjalizmie), to nie będą istnieć na większą skalę legalne przedsiębiorstwa prywatne, ponieważ taki zakaz da się wyegzekwować. Będzie więc monopol przedsiębiorstw państwowych.

Jeżeli dobrowolne transakcje uzna się za przestępstwo (a dobrowolne transakcje to rynek), a jakaś koordynacja $\mathrm{w}$ gospodarce jest potrzebna, to, co wchodzi $\mathrm{w}$ tę pustkę? Wchodzi centralne planowanie, czyli mechanizm nakazowo-rozdzielczy. Zatem widać, jakie są zależności między tymi trzema członami. Porządek prawny, jeżeli nie jest tylko na papierze (nie jest dekoracyjny), silnie kształtuje system organizacji, a także to, jakie interakcje w społeczeństwie sa dozwolone.

Istota socjalizmu był monopol własności państwowej. A w jaki sposób egzekwowano ten monopol? Po pierwsze przez nacjonalizację w punkcie startu wszystkiego, co było prywatne, oraz przez zakaz tworzenia i rozwoju firm prywatnych. Występowały pewne odchylenia od tego monopolu, np. w Polsce nie skolektywizowano rolnictwa, ale były one marginesem.

$\mathrm{Na}$ ustroje warto patrzeć z punktu widzenia tego, jakie rodzaje czynów są uznawane przez państwowe prawo za przestępstwo. Gdy patrzymy z lotu ptaka na nowożytne ustroje, dostrzegamy, że w ich porząlku prawnym istnieje pewien wspólny zbiór czynów uznawanych za przestępstwa. Nazwijmy je przestępstwami elementarnymi. Ich przykłady to zabójstwo, oszustwo, kradzież itd. Co jest cechą charakterystyczną niektórych ustrojów, zwłaszcza socjalizmu? To, że ich systemy prawa obejmowały dodatkowy duży zbiór czynów uznawanych za przestępstwa - określane jako przestępstwa polityczne (albo przestępstwa przeciw socjalizmowi). A co było przestępstwem w socjalizmie? Każda próba wykorzystywania jakiejś klasycznej wolności. Własność prywatna, która jest klasyczną wolnościa, była przestępstwem. Organizowanie się bez zgody państwa było przestępstwem. Stowarzyszanie się - co jest rdzeniem społeczeństwa obywatelskiego - było przestępstwem. Publiczna krytyka władz była przestępstwem. Nawiasem mówiąc, mamy te przeżytki jeszcze w naszym Kodeksie karnym. Popełnianiu tych przestępstw przeciwdziałała policja polityczna SB, KGB - inaczej socjalizm by się nie utrzymał. Czyli jego istotą była ogromna represyjność. Nie jest przypadkiem, że żaden ustrój socjalistyczny definiowany przez monopol własności państwowej nie był demokratyczny. Myśleć o demokratycznym socjalizmie było (i jest) mrzonka. Poniżej przytoczono kilka przykładów z Kodeksu karnego z 1969 r. 
Art. 133

$\S 1$ Kto publicznie nawołuje do czynów skierowanych przeciwko jedności sojuszniczej Polskiej Rzeczypospolitej Ludowej z państwem sprzymierzonym albo takie czyny publicznie pochwala, podlega karze pozbawienia wolności od roku do lat 10.

$\S 2$ Przepis $§ 1$ stosuje się, jeżeli państwo sprzymierzone zapewnia wzajemność.

Art. 222

Kto, nie mając uprawnień handlowych, gromadzi w celu odprzedaży z zyskiem towary w ilościach oczywiście niewspółmiernych do potrzeb własnych jako konsumenta, podlega karze pozbawienia wolności do lat 3.

Art. 237

Kto znieważa organ państwowy lub organizację polityczna, związek zawodowy, stowarzyszenie wyższej użyteczności publicznej lub inną organizację społeczna o znaczeniu ogólnopaństwowym w miejscu ich zajęć albo publicznie, podlega karze pozbawienia wolności do lat 2 , ograniczenia wolności albo grzywny.

Art. 278

§ 1. Kto bierze udział w związku, którego istnienie, ustrój lub cel ma pozostać tajemnicą wobec organów państwowych albo który rozwiązano lub któremu odmówiono zalegalizowania, podlega karze pozbawienia wolności do lat 3 .

$\S 2$. Kto związek taki zakłada lub nim kieruje, podlega karze pozbawienia wolności od 6 miesięcy do lat 5.

§ 3. Kto pełni czynności kierownicze w związku, który rozwiązano lub któremu odmówiono zalegalizowania, podlega karze pozbawienia wolności od 6 miesięcy do lat 5 .

$\S 4$. Nie podlega karze za przestępstwo określone w $\S 1$, kto dobrowolnie odstąpił od udziału w związku.

Ukoronowaniem listy przestępstw politycznych było łamanie tajemnicy państwowej, która obejmowała wszystko. Gdy np. ktoś zdradził, że państwo kogoś prześladowało, mógł łamać tajemnicę państwową i stać się przestępca.

Oczywiście socjalizm zmieniał się pod względem represyjności: o wiele gorzej było w stalinowskiej fazie socjalizmu niż po 1956 r. Ale jego istota, tzn. traktowanie jako przestępstw wszelkich prób wykorzystania klasycznych wolności, pozostała, inaczej bowiem socjalizm by się rozsypał.

Ten ustrój nie tylko odbierał ludziom podstawowe wolności, lecz także skazywał ich na zacofanie w stosunku do Zachodu. Każdy kraj socjalistyczny tracił dystans w stosunku do krajów kapitalistycznych, które kiedyś były na podobnym poziomie rozwoju gospodarczego. Polska i Hiszpania w $1950 \mathrm{r}$. miały podobny poziom dochodu na głowę mieszkańca. W 1990 r. Polska miała tylko 42\% dochodu Hiszpanii. Dopiero od 1989 r. redukujemy narosły dystans wobec Zachodu. On się pojawił 300 lat temu, a wydatnie powiększył za czasów PRL. Na tym tle warto patrzeć na znaczenie przemian, które rozpoczęły się po 1989 r. Trzeba jednak pamiętać, że demokracja nie gwarantuje wszelkich indywidualnych swobód. W ustroju demokratycznym niektóre wolności są celem szczególnych ataków, zwłaszcza wolność gospodarcza - szeroko rozumiana wolność praktycznego czynu. 


\section{ZMIANY INSTYTUCJONALNE PO SOCJALIZMIE}

Po 1989 r. początkowo wydawało się, że wszystkie kraje dawnego bloku socjalistycznego idą w tym samym kierunku, tzn. w kierunku demokracji, państwa prawa oraz gospodarki kapitalistycznej. Później się to rozszczepiło. Inną drogą idzie Rosja (zwłaszcza za czasów Putina), jeszcze inną Białoruś za czasów Łukaszenki. Na drodze do demokracji i rynku utrzymały się kraje Europy Środkowo-Wschodniej, w tym Polska.

$\mathrm{Na}$ czym polegały najważniejsze zmiany instytucjonalne po socjalizmie? Jeżeli będziemy się trzymać podziału na porządek prawny, system organizacji oraz mechanizmy współdziałania między ludźmi, to można powiedzieć tak: w krajach, które utrzymały się na drodze demokracji, przede wszystkim usunięto z porządku prawnego przestępstwa przeciw socjalizmowi - korzystanie z elementarnych wolności przestało być przestępstwem. Własność prywatna, przedsiębiorstwa prywatne przestały być przestępstwem. To samo dotyczy wolności słowa, zgromadzeń, stowarzyszania się itp. Nastapiła więc wielka prawna liberalizacja. Nie zostało to w pełni dokończone. Na przykład mamy w Kodeksie karnym także dosyć „kauczukowe” przepisy, np. można być ściganym przez prokuratora za „niegospodarność”. Niemniej przełom się dokonał.

Po drugie, ogromne zmiany nastapiły w systemie organizacji. Mieliśmy system monopartyjny, a teraz mamy system wielopartyjny, czyli zakładanie partii przestało być przestępstwem. A było - największą zbrodnią było zakładanie partii opozycyjnej. Dlaczego „Solidarność” w 1980 r. przybrała postać związku zawodowego, choć była daleko czymś więcej? Bo gdyby nazwała się partią opozycyjna, to władza by ostro zareagowała, również zewnętrzna.

Powstały demokratyczne władze lokalne, nazywane samorządem. Nawiasem mówiąc, nazwa jest niewłaściwa - to jest państwowa władza lokalna. Przeciwstawianie samorządu i państwa jest absurdem.

Armia została oddzielona od jednej partii, ponieważ nie ma już tylko jednej partii. Policja - która kiedyś była zainfekowana ściganiem dysydentów (choć zajmowała się tym głównie Służba Bezpieczeństwa), została odpolityczniona. Dochodzimy do prokuratury, która niegdyś dominowała nad sądem. Pytanie, w jakim stopniu nastapiły tu zmiany. To pytanie dla prawników - praktyków. Myślę, że tu nadal jest wiele do zrobienia.

Nastapiło wreszcie wyzwolenie mediów, choć wolności mediów, zwłaszcza lokalnych, ciagle trzeba pilnować.

Radykalnie zmieniła się organizacja gospodarki: w Polsce zniesiono niemal wszystkie organizacje monopolizujace gospodarkę (resorty, zrzeszenia, centralne związki spółdzielcze). Było to wielkie wyzwolenie konkurencji.

I wreszcie dzięki usunięciu z Kodeksu karnego przepisów, które transakcje dobrowolne traktowały jako zbrodniczą spekulację, mamy rynek. A dzięki demonopolizacji ten rynek jest w miarę konkurencyjny. Bez konkurencji własność prywatna nie działa najlepiej.

Jak widać, nastapiły ogromne zmiany, choć nie we wszystkich punktach dokończone. Jak już powiedziałem - bez dostatecznej mobilizacji społeczeń- 
stwa obywatelskiego w obronie wolności i praworządności zawsze grozi zastój lub regres. Dlaczego np. wprowadza się przepisy, które mają chronić przed konkurencją (np. przez licencjonowanie). Na przykład jeśli jakieś biuro podróży zbankrutuje i zostawi swoich klientów za granica, na co są naciski mediów? Na wprowadzenie licencji, żeby się to nie powtórzyło, ale jeśli się wprowadzi na szeroką skalę licencje, to się ogranicza konkurencję. Czyli duża część antykonkurencyjnej legislacji bierze się z grupowych nacisków, które nie natrafiają na przeciwwagę.

Jak wspomniałem, po socjalizmie nastapiły również - przynajmniej w niektórych krajach - ogromne zmiany w systemie organizacji. Chodzi tu o trzy typy zmian:

Pierwsza to likwidacja odziedziczonych organizacji, tzn. tych, które najsilniej były związane z socjalizmem jako systemem wszechrepresji (cenzura, SB, organy monopolizujace gospodarkę). Gdy się porównuje kraje posocjalistyczne, widać duże różnice w stopniu likwidacji organizacji najbardziej typowych dla socjalizmu. Na przykład w Rosji KGB stało się czymś innym tylko z nazwy, ale struktura się niewiele zmieniła (na Białorusi jeszcze mniej).

Drugim typem przemian były przekształcenia organizacji, które można podzielić na:

1) Odgórne - wszystkie organy publiczne uznawane za niezbędne mogły być przekształcone tylko odgórnie (np. administracja publiczna, policja, prokuratura, sądy);

2) Oddolne - prywatyzacja przedsiębiorstw. Nie władza publiczna je przekształca, ale przekształca je prywatny inwestor.

Socjalizm to była niemal stuprocentowa dawka monopolu własności państwowej. W Europie Zachodniej występowały po II wojnie światowej dużo mniejsze dawki tej własności (10-20\%), np. w Wielkiej Brytanii, Francji czy Włoszech. Kraje Zachodu wypróbowały wszystkie metody reformy sektora państwowego w gospodarce i żadne nie przyniosły zamierzonych efektów. Zaczęły więc prywatyzować. Pierwsza zaczęła to robic Margaret Thatcher w Wielkiej Brytanii, ale największe prywatyzacje nastapiły we Francji i Włoszech. Wspominam o tym, aby pokazać, że sektor państwowy, pozbawiony konstytutywnej wady, jaka jest upolitycznienie i związana z tym nieefektywność - jest mrzonka.

Trzeci typ zmian organizacyjnych po socjalizmie to oddolne tworzenie nowych organizacji. Skupię się tu na prywatnych przedsiębiorstwach, ale ta zmiana obejmuje również zakładanie fundacji i stowarzyszeń, które tworzą tzw. trzeci sektor.

\section{ROZWIAZZANIA INSTYTUCJONALNE A ROZWÓJ GOSPODARKI}

Dla rozwoju gospodarki zasadnicze znaczenie ma typ prawa własności. Socjalizm upadł dlatego, że był oparty na monopolu własności państwowej. Taki monopol oznacza bowiem totalne upolitycznienie gospodarki. 
Podstawowe rozróżnienie dotyczy więc prawa własności: czy ono zakazuje przedsiębiorstw prywatnych, czy je dopuszcza. Jeżeli je dopuszcza nie na papierze, a faktycznie, to zawsze będzie pojawiał się sektor prywatny. Oczywiście, w jakim tempie i zakresie zależy od innych warunków: administracyjnych, od sposobu działania rozmaitych agend administracji (np. ile będzie inspekcji) i jakie sa podatki, których wysokość wyłącznie zależy od wydatków budżetowych. A zatem oburzanie się na wysokie podatki jest czynnościa jałowa, jeżeli abstrahuje się od przyczyny, czyli dużych wydatków budżetu.

Badając różnice w krajowym prawie własności, należy uwzględnić nie tylko jego treść, ale i poziom ochrony zawartych w niej uprawnień, czyli trzeba patrzeć na działania aparatu państwowego. Jeżeli prywatny przedsiębiorca inwestuje kapitał, to oczekuje minimum zwrotu nakładów i jeszcze jakiegoś zysku. Tu pojawia się problem ochrony ludzi i ich własności przed pospolita przestępczością. Dochodzimy w ten sposób do tej części systemu sprawiedliwości, który po angielsku nazywa się criminal justice system. Jeżeli pospolita przestępczość, tzn. przeciwko życiu i mieniu, jest masowa, to nie będzie inwestycji prywatnych, ponieważ inwestorzy prywatni uznaja, że nie odzyskaja kapitału. Ilustruje to porównanie dwóch krajów o podobnej kulturze i leżących na tej samej wyspie: Haiti i Dominikany.

\section{Wykres 1}

Stopień ochrony prawa własności przed pospolitą przestępczością zapewniony przez aparat państwowy
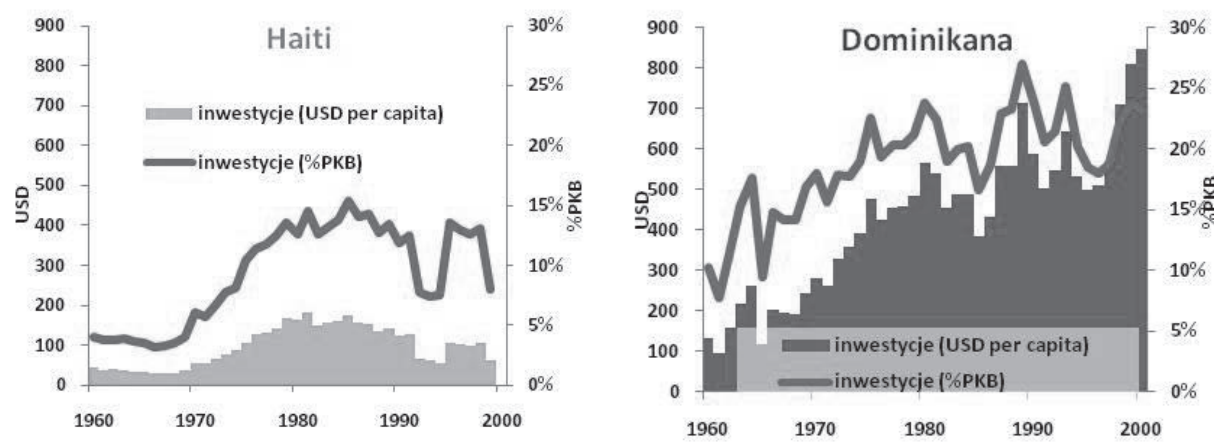

W 1950 r. leżące na jednej wyspie Haiti i Dominikana były na zbliżonym poziomie rozwoju. Obecnie Dominikana jest ok. 6-7 razy bogatsza od Haiti. Jednym z głównych źródeł różnego tempa wzrostu jest niski poziom inwestycji na Haiti. Małe inwestycje zaś można wiązać m.in. z brakiem bezpieczeństwa. Przykładowo w ankiecie z 2006 r. 30\% Haitańczyków stwierdziło, że na przestrzeni ostatnich 12 miesięcy zostało napadniętych i/lub obrabowanych. Dla Dominikany analogiczny wskaźnik wyniósł 11\%.

Źródło: Gallup, Sandeep Mahajan, 2002, OxLAD.

Dominikana jest daleka od ideału, ale na Haiti jest dużo gorzej. Haiti, gdzie właściwie nie ma państwa w jego zasadniczej funkcji: ochrony przed pospolita przestępczościa, jest bardzo mało inwestycji prywatnych i jest stagnacja. W Dominikanie, gdzie przestępczość jest nadal wysoka, ale nie tak katastrofalna, jest dużo więcej prywatnych inwestycji. 
Inny przykład. Dziesięć lat temu przeprowadzono badania właścicieli sklepów w Moskwie i w Warszawie. Badania pokazały, że właściciele sklepów w Warszawie inwestują wyższy odsetek swoich zysków niż w Moskwie. Dlaczego? Badania pokazały, że zaufanie do policji jest większe w Warszawie niż w Moskwie: policjant w Warszawie jawił się bardziej jako strażnik niż rabuś, w Moskwie - odwrotnie.

Ilustrują to poniższe zestawienia

Wykres 2

Stopień zagrożenia prawa własności przez aparat państwowy

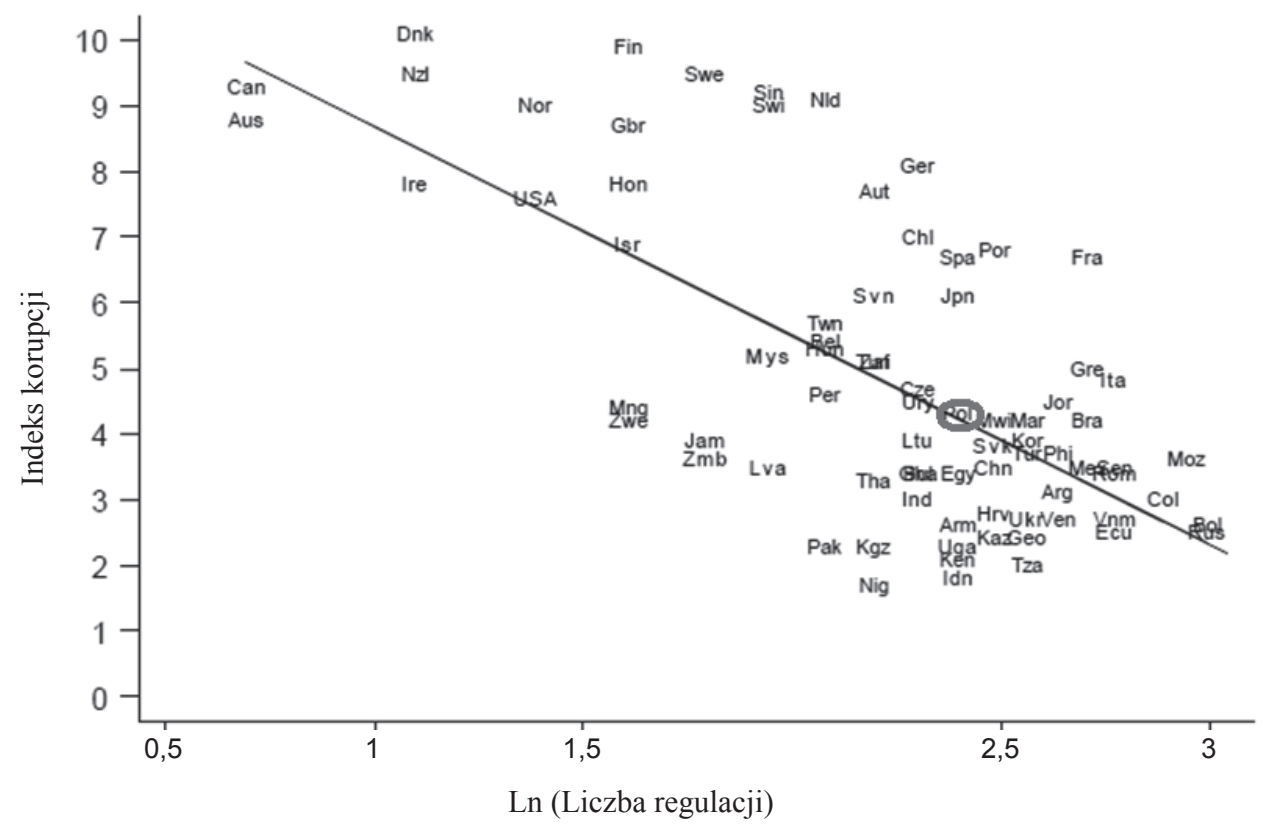

Korupcja a liczba regulacji. Wykres pokazuje wartość indeksu korupcji w stosunku do liczby regulacji (log) dla 78 państw, dla których dostępne są dane na temat korupcji. (Skrócone nazwy państw podano w języku angielskim).

Źródło: The Regulation of Entry, S. Djankov, R. La Porta, F. Lopez de Silanes, A. Shleifer, June 2001.

Zagrożenie jednak nie pochodzi tylko od osób prywatnych, zagrożenie własności prywatnej może też pochodzić ze strony funkcjonariuszy państwa chodzi tu o korupcję, którą można traktować jako dodatkowy podatek.

Istnieje silny związek między nadmiernymi regulacjami a korupcją. Jeżeli bowiem stosowanie się do określonych przepisów jest dla przedsiębiorcy bardzo kosztowne, to w przypadku urzędnika pojawia się np. możliwość: nie będę egzekwował przepisu, jeżeli zapłacisz mi sumę, która będzie mniejsza od kosztów, jakie poniósłbyś, gdybym go egzekwował. Jeżeli chce się rzeczywiście zmniejszyć natężenie korupcji, to trzeba usunąć jej główne źródło: nadmierne 


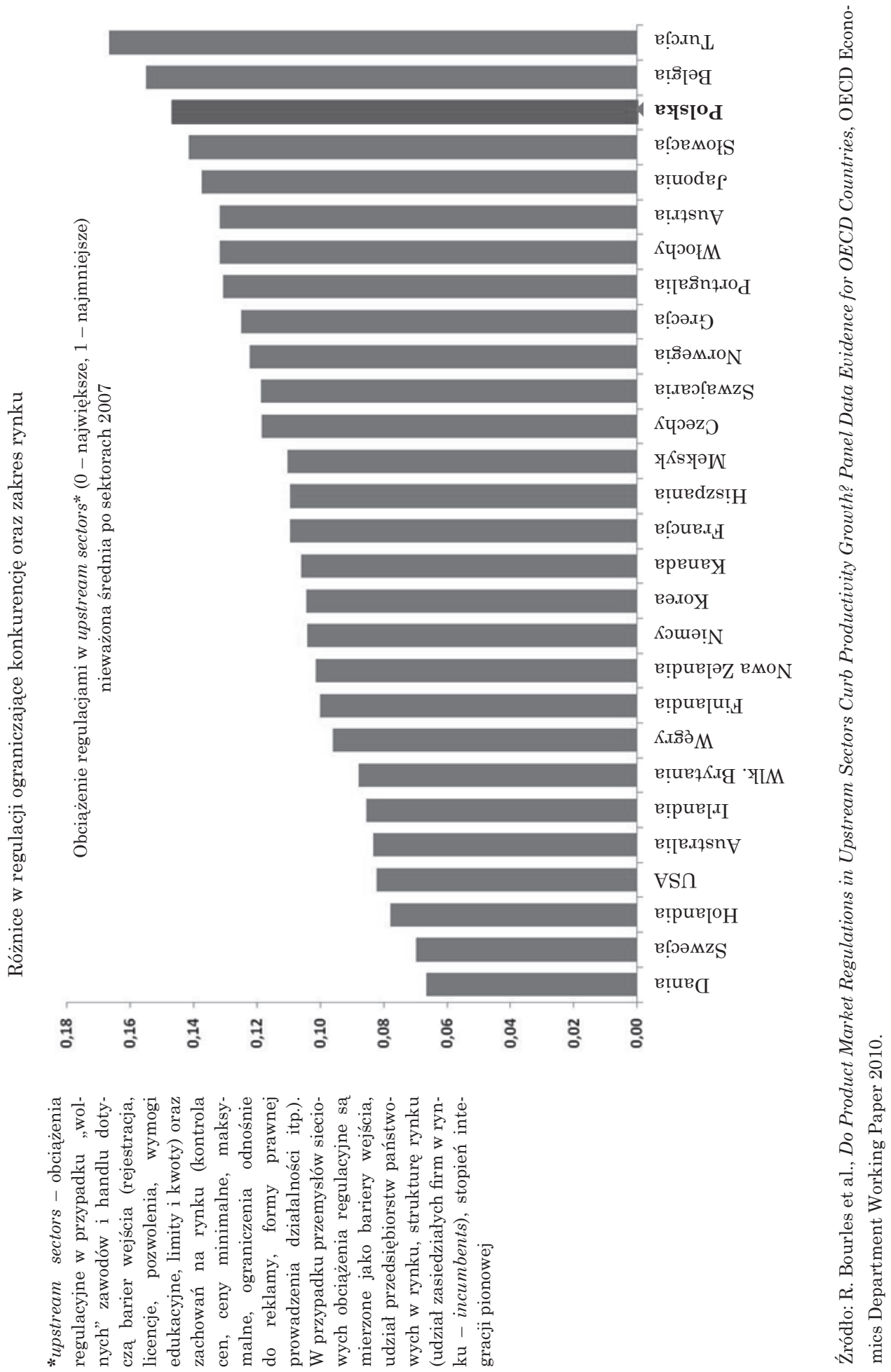


regulacje. Nie mówię o korupcji na szczytach, ale takiej masowej korupcji na poziomie aparatu państwowego. Badania również pokazały, że jeżeli prywatny przedsiębiorca ma przed sobą perspektywę nękających regulacji i inspekcji, to albo się zgodzi na dodatkową opłatę (tzn. „podatek korupcyjny"), albo może dojść do wniosku, że bardziej mu się opłaca działać w szarej strefie. Ale w szarej strefie też jest potrzebne rozstrzyganie sporów i ochrona własności, nie można jednak skorzystać z legalnego aparatu. Korzysta się więc z mafii. To pokazują wyniki badań empirycznych w krajach byłego ZSRR. Nawiasem mówiąc, na poziomie praktycznych definicji dość trudno rozróżnić państwo i mafię (Korea Północna, ZSRR za Stalina, Chiny za Mao, Kambodża za Czerwonych Khmerów - to przykłady państw gorszych od mafii).

Oprócz typu prawa własności działanie gospodarki zależy od ilości regulacji, które ograniczają rynek lub konkurencję na rynku. Na przykład kontrola czynszów. Jeżeli jest tego typu, że się nie opłaca inwestować, dlatego że się nie odzyska kapitału, to sektor prywatny nie będzie inwestował w budowę mieszkań na wynajem, ale mieszkania będą nadal potrzebne. W efekcie państwo będzie wkraczać jako zbawiciel. Jeżeli lokatora się tak chroni, że nie można go wyrzucić, nawet gdy niszczy mieszkanie, to kto zainwestuje? To sa tylko przykłady regulacji, które wypierają rynek, a stwarzają fałszywe wrażenie, że rynek zawodzi, w związku z tym państwo musi interweniować. Ale rynek zawodzi najczęściej wtedy, kiedy państwo nie dopuszcza do jego działania. W efekcie powstaje spirala interwencjonizmu.

Mamy też liczne regulacje ograniczające konkurencję, wprowadzane zwykle pod naciskiem różnych grup interesu. W Polsce zawody zamknięte nazywają się „wolnymi”.

Adam Smith, osiemnastowieczny wielki filozof i ekonomista, sformułował bardzo ważne i sprawdzalne empirycznie twierdzenie, że rozwój gospodarki jest związany z rozszerzaniem się zakresu rynku, czyli liczby transakcji. A liczba transakcji to są umowy, różnego typu. Liczba transakcji zależy od tego, jak są egzekwowane umowy, co m.in. zależy od działania sądów. Działanie sądów jest więc istotne dla gospodarki.

Wykres 3 pokazuje, jakie jest obciążenie gospodarki regulacjami, które ograniczają konkurencję. Polska była na trzecim miejscu od końca, gorzej było w Turcji i - o dziwo - w Belgii. Zostało więc dużo do zrobienia. A od strony pozytywnej - możemy mieć duże rezerwy wzrostu, jeżeli hasło deregulacji będzie realizowane tam, gdzie jest ono najbardziej potrzebne. Dania, Szwecja i Finlandia - kraje, które uchodzą za państwa socjalne mają więcej wolnego rynku niż ogromna większość krajów Europy. I to jest ważniejsze wyjaśnienie ich sukcesów. Wykres 4 pokazuje, ile mogłyby poszczególne kraje uzyskać $\mathrm{w}$ postaci wzrostu produktywności gospodarki, gdyby wprowadziły zdecydowaną deregulację. Jak widać, Polska jest tu w czołówce. 


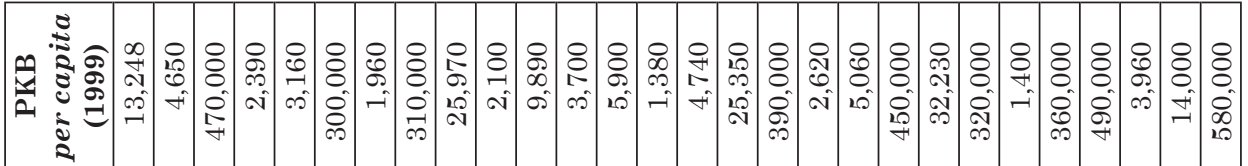

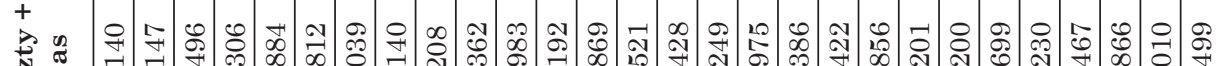

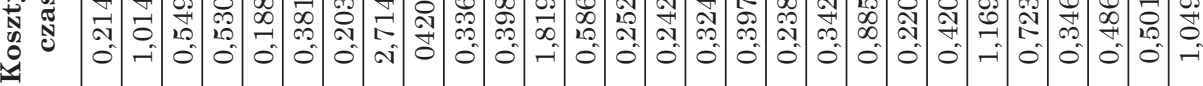

在

U

先

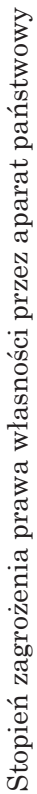

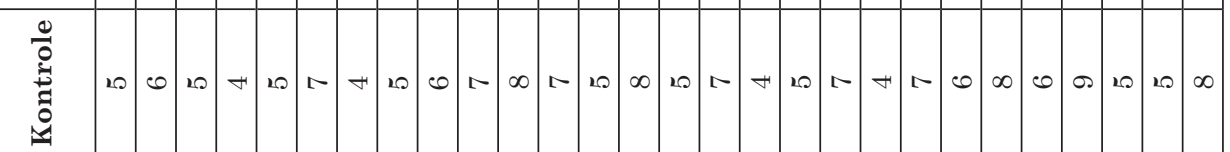

.

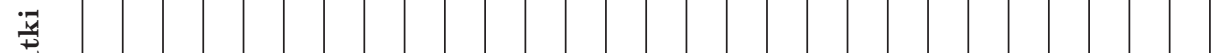

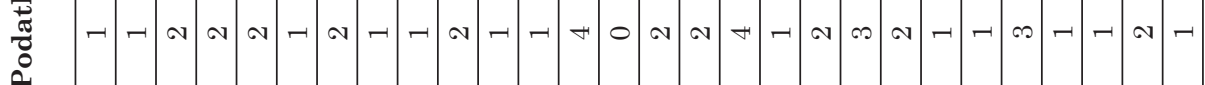

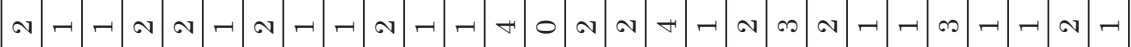

$\frac{3}{5}$

象

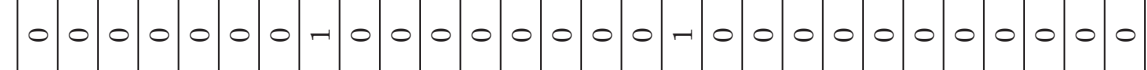

ำำ

3.

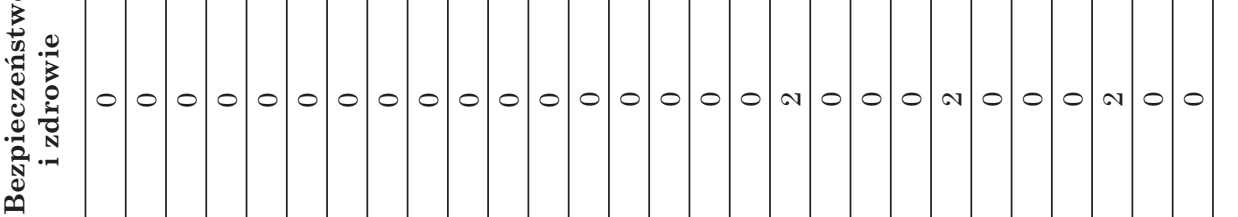

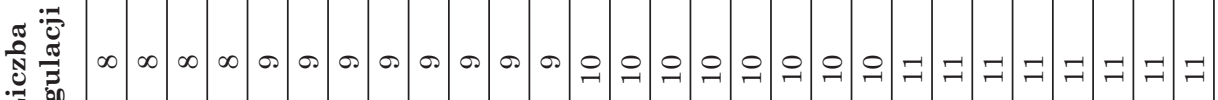

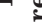

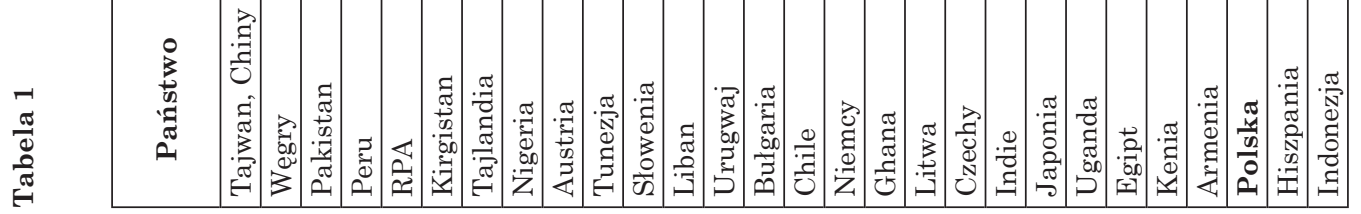

वे

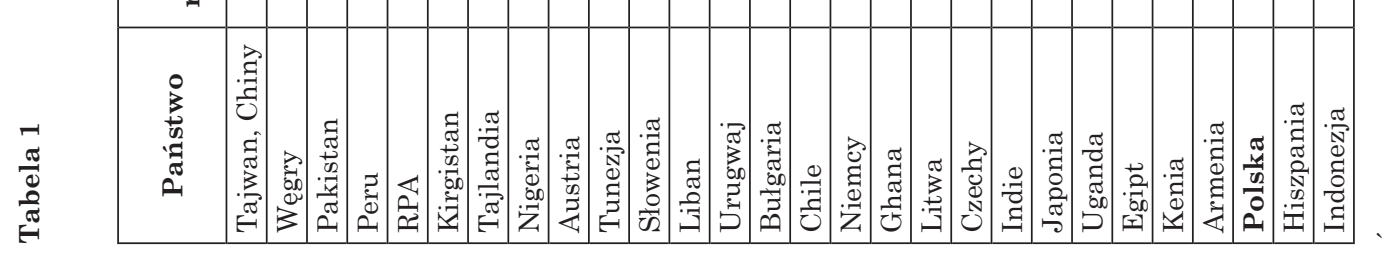




\section{Wykres 4}

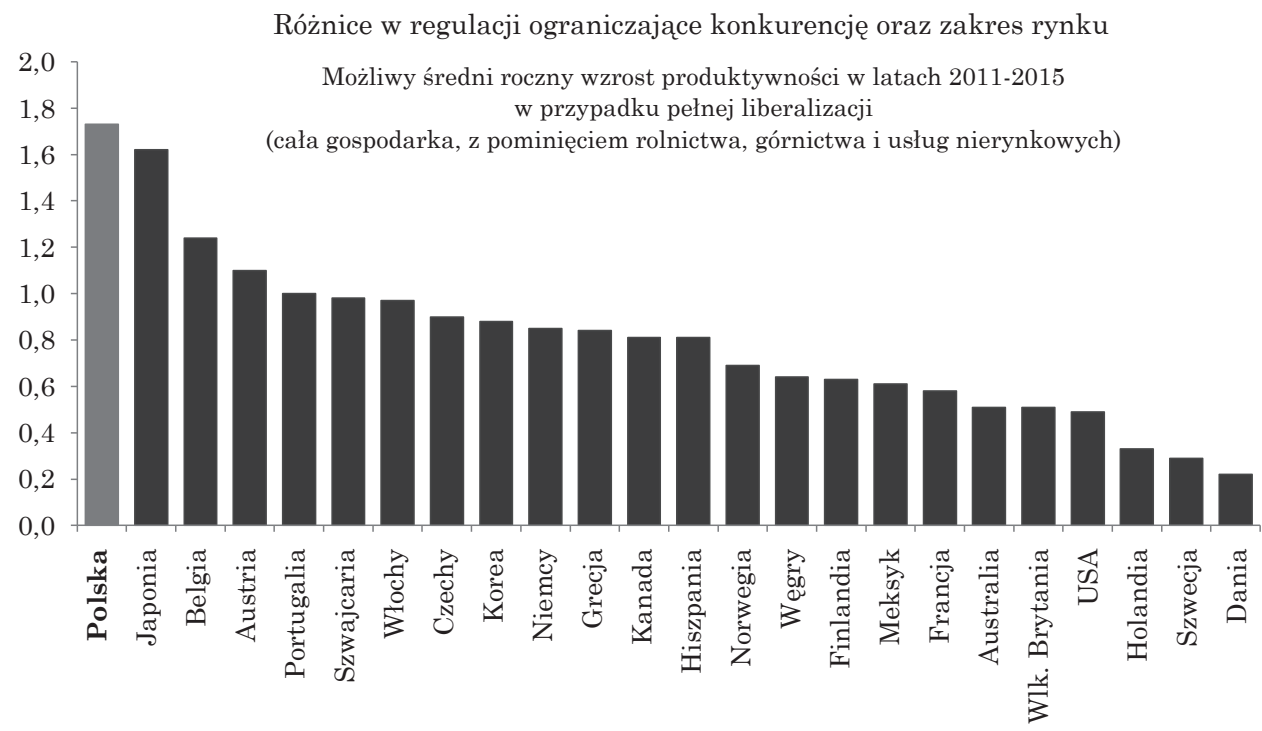

$101,7 \% \wedge 5=108,8 \%$, co w warunkach PKB z 2010 r. daje PKB wyższy o ok. 125 mld zł.

*Symulacje OECD bazują na założeniu, że państwa dostosują regulacje w poszczególnych upstream sectors do poziomu najlepszych praktyk zaobserwowanych w krajach OECD.

Źródło: R. Bourles et al., op. cit.

\section{WYMIAR SPRAWIEDLIWOŚCI: (NIE)EFEKTYWNOŚĆ I (NIE)SPRAWIEDLIWOŚĆ}

Na koniec przejdę do podstawowych wymiarów jakości działania wymiaru sprawiedliwości. Jako człowieka, który zajmuje się badaniem instytucji w Polsce, dziwi mnie to, że jest zadziwiajaco mało empirycznych analiz wymiaru sprawiedliwości jako pewnego systemu. Chodzi tu o dwie kwestie:

1) Jak efektywny jest wymiar sprawiedliwości? Przez efektywność rozumiem tu szybkość jego działania.

2) W jakiej mierze jest sprawiedliwy? Z samego faktu, że coś się nazywa wymiarem sprawiedliwości, nie wynika jeszcze, że jest on sprawiedliwy - zarówno na etapie ścigania, jak i orzekania.

Jakie sa relacje między tymi dwoma wymiarami? Po pierwsze może być wysoka efektywność i rażąca niesprawiedliwość (np. procesy stalinowskie bardzo efektywne i bardzo niesprawiedliwe). Po drugie, gdy jest niska efektywność: długie i przewlekłe postępowania, przetrzymywanie ludzi w aresztach wydobywczych, czy to może być sprawiedliwie? Chyba nie - za ilustrację niech posłuży cytat z najsłynniejszego premiera wielkiej Brytanii XIX w. Williama Gladstona, który głównie interesował się teologia, ale był też wspania- 
łym ministrem skarbu: „Justice delayed is justice denied” („Opieszałość wymiaru sprawiedliwości oznacza brak sprawiedliwości”).

Czyli istnieje związek między nieefektywnością a sprawiedliwościa. Najlepszym rozwiązaniem jest rzecz jasna wysoka efektywność i wysoka sprawiedliwość.

Jeżeli w danej dziedzinie jest niska efektywność, to jaki jest tego powód? Wynika to zwykle ze złego rozłożenia zadań między jednostkami. Jeżeli w miejscach, w których jest mało zadań, jest dużo wykonawców, a w tych, w których jest dużo zadań - mało, to oczywiście efektywność będzie niska. Ekonomiści nazywają to efektywnościa alokacji - musi być proporcjonalność między liczba zadań a wielkościa zasobów. W Polsce ta zasada jest łamana (małe szkoły, małe sądy itd.).

Kolejna rzecz to zła organizacja pracy oraz stosowanie przestarzałych technologii. Inną przyczyną spoza wymiaru sprawiedliwości jest jego „zamulanie”. Na przykład notoryczne donoszenie do prokuratury przez polityków na innych polityków - to trzeba ośmieszyć.

Niska efektywność polskiego wymiaru sprawiedliwości nie wynika z jego niedoinwestowania. Polska wydaje dużo jako odsetek PKB. Jako minister finansów w latach 1997-2000 w swojej naiwności też liczyłem na to, że jeśli będzie tam więcej pieniędzy, to będzie więcej reform.

Weźmy relatywnie dużą liczbę sędziów. Wykres 5 ilustruje podstawowa miarę: liczbę spraw na jednego sędziego. W Polsce jest ona średnio bardzo mała.

Wykres 5

Dwa zasadnicze wymiary sprawiedliwości - (nie)efektywność sądownictwa

Wpływ spraw ogółem

Współczynnik na jednego sędziego

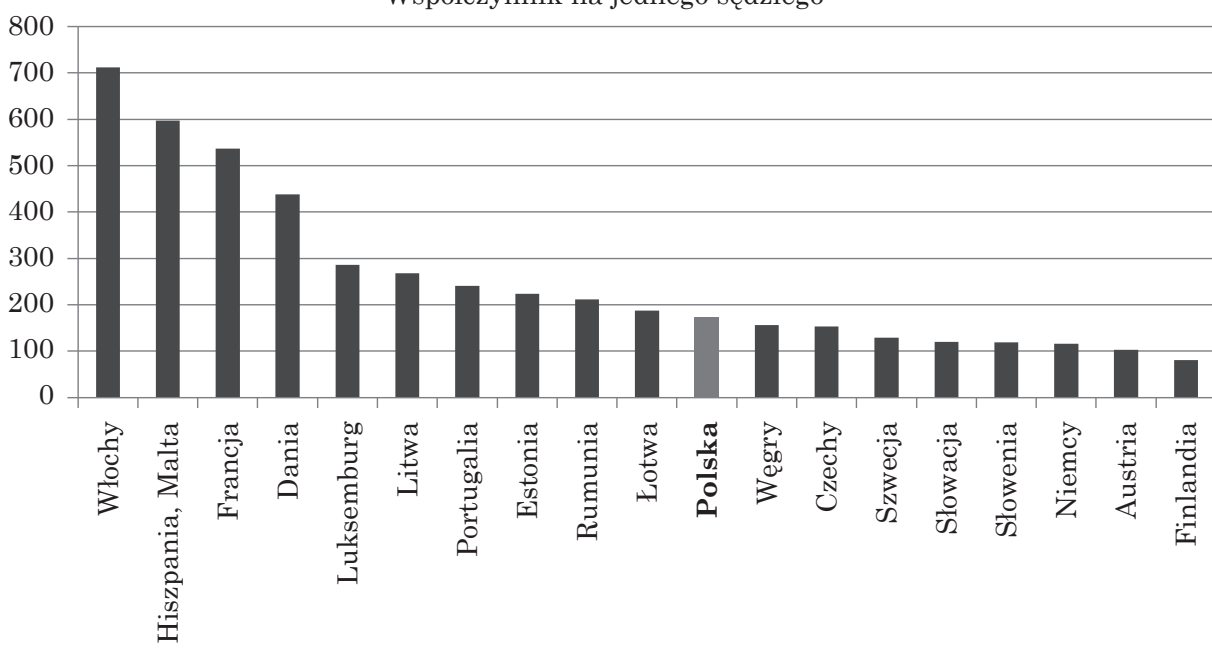

Źródło: European Judicial Systems Edition 2010 (data 2008): Efficiency and Quality of Justice, Council of Europe. 
Nawiasem mówiąc, na tle innych krajów zachodnich mamy mały rejestrowany wskaźnik przestępczości. Oczywiście inne pytanie to, jaki odsetek przestępstw jest podejmowanych, ale to trudniej zbadać. Nie należymy jednak, na tle Europy, do krajów o masowej przestępczości. Na początku (po 1989 r.) wzrósł ogromnie jeden typ przestępczości - kradzież samochodów, ponieważ było więcej samochodów, poza tym aparat policyjny nie był dostosowany, potrzebował na to czasu. Przestawił się jednak i teraz ta przestępczość jest dużo mniejsza.

Wykres 6

Dwa zasadnicze wymiary sprawiedliwości - (nie)efektywność prokuratury

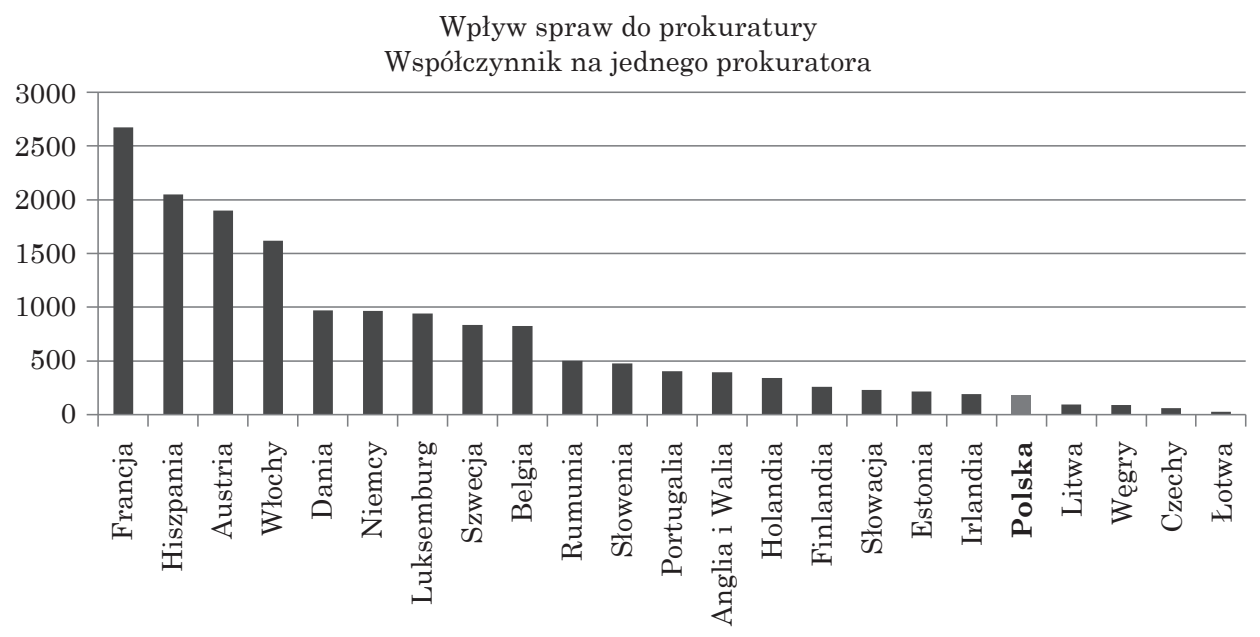

Źródło: European Judicial Systems Edition 2010 (data 2008): Efficiency and Quality of Justice, Council of Europe.

Przejdę do drugiego zagadnienia, tj. niesprawiedliwości w wymiarze sprawiedliwości - na etapie ścigania i skazywania ludzi, co jest bardziej drastyczne niż opieszałość, ponieważ dotyczy słuszności aresztowań i słuszności skazań. Na etapie ścigania można popełnić jeden z błędów: można ścigać niewinnych i można nie ścigać winnych. Przy czym jeżeli przyjmiemy, że ściganie niewinnego jest czymś gorszym moralnie niż nieściganie winnego, to trzeba większą wagę przykładać do ścigania niewinnych. Bardzo mało jest badań w Polsce, które pokazywałyby, jaki jest odsetek ścigania - a co gorsza - skazywania osób niewinnych. Nie oznacza to jednak, że nie mamy tego problemu.

Profesor Andrzej Rzepliński powiedział kiedyś publicznie coś, co mi utkwiło w pamięci: bycie niesłusznie ściganym to jest jak gwałt, życie takiej osoby jest zrujnowane. Jeżeli ktoś będzie ścigany przez ileś lat, a później uniewinniony - to już nie jest to samo życie. Zatem problem jest bardzo drastyczny. 
Ściganie niewinnych czy - co gorsza - skazywanie niewinnych jest rezultatem określonych decyzji określonych ludzi: policjantów, prokuratorów, sędziów. Te decyzje zależą od jakości ludzi oraz od bodźców, jakim oni podlegają. Nie można zakładać, że w wymiarze sprawiedliwości będą pracować sami aniołowie. Mechanizmy selekcji są oczywiście bardzo ważne, ale równie ważne są systemy bodźców: za złą pracę należy ponosić odpowiedzialność. W wypadku prokuratora są to decyzje dotyczące umorzenia sprawy czy nadania jej biegu.

\section{Diagram 1}

Wskaźnik (nie)sprawiedliwości w działaniu aparatu ścigania (policja, prokuratura)

P - liczba przestępstw w kraju*

S - liczba osób ściganych w danym kraju (zakłada się dla uproszczenia, że każde przestępstwo ma tylko jednego sprawcę)

$\mathrm{N}$ - liczba niewinnych, którzy są ścigani

NW - liczba przestępstw, w przypadku których nie podejmuje się dochodzenia

Jeśli ściganie niewinnych uznajemy za większe zło niż nieściganie winnych, to trzeba wprowadzić odpowiednie wagi, np.

$$
\begin{aligned}
& a_{1}=2-\text { ściganie niewinnych } \\
& a_{2}=1-\text { nieściganie winnych. }
\end{aligned}
$$

* Pomija sie tu problem traktowania jako przestęstw czynów nieprzestęczych, między innymi z powodu ogólnikowego charakteru norm prawa karnego, dopuszczajacych przy złej woli lub niekompetencji ścigajacych taka interpretację.

$$
W S=\frac{a_{1} \cdot N+a_{2} \cdot N W}{P}
$$

Skrajne przypadki:

1. We wszystkich przypadkach $\mathrm{P}$ ściga się tylko winnych, czyli: $\mathrm{N}=0, \mathrm{NW}=0 \rightarrow W S=0$ tzn. pełna trafność (doskonała sprawiedliwość).

2. We wszystkich przypadkach $\mathrm{P}$ ściga się tylko niewinnych. Czyli: $\mathrm{N}=\mathrm{P}, \mathrm{NW}=0 \rightarrow$ $\rightarrow W S_{p}=\frac{2 \times P}{P}=2$ (pełna niesprawiedliwość).

3. Sprawców żadnych przestępstw się nie ściga, czyli: $\mathrm{NW}=\mathrm{P}, \mathrm{N}=0, W S_{p}=\frac{p}{p}=1$
(pełna bierność prokuratora). Jak widać, wskaźnik (nie)sprawiedliwość w działalności aparatu ścigania może przybierać wartości:

$0 \leqslant W S \leqslant 2$. 
Jeżeli system bodźców w prokuraturach jest taki, że prokurator nie naraża się na określone kary, jeśli będzie ścigał ludzi bez dostatecznych dowodów, to takie działania będą się powtarzać. Pojawia się tu m.in. pytanie: Jaka moc w praktyce, a nie przepisach, ma przyznanie się do winy oskarżonego w przyczynianiu się do skazania? Jeżeli w praktyce przyznanie się oskarżonego do winy jest istotne, to będzie istnieć presja na wymuszanie takiego przyznania. Czym w średniowieczu różniło się prawo angielskie od kontynentalnego? W prawie angielskim zmniejszono wagę przyznania się do winy, a w kontynentalnym - nie. W związku z tym pojawiło się na kontynencie zapotrzebowanie na tortury jako mechanizm wydobywania przyznania się do winy. Czy odpowiednikiem tortur nie jest stosowanie w Polsce aresztów „wydobywczych”?

Podam liczbę, która mną wstrząsnęła. Została ona podana przez prokuratora generalnego Andrzeja Seremeta, który - broniąc prokuratury - powiedział, że w niemal 99\% przypadkach sądy skazują zgodnie z wnioskami prokuratury. Wyższy wskaźnik jest w Uzbekistanie (99,8\%). Czy jest to właściwy wskaźnik sukcesu prokuratury? Jeżeli np. współczynnik niesłusznych ścigań jest 10\%, a współczynnik uniewinnień 1\%, to nawet jeśli założymy, że ten 1\% dotyczy tych 10\% niesłusznie ściganych, to 9\% jest nie tylko ściganych, lecz także niesłusznie skazanych.

Pełna sprawiedliwość jest wtedy, kiedy ściga się wyłącznie winnych, a nie ściga niewinnych. To jest ideał, do którego trzeba dążyć, tak jak w lotnictwie dąży się do tego, by współczynnik katastrof wynosił zero.

\section{PODSUMOWANIE}

W Polsce w wielu dziedzinach ogromnie i pozytywnie zmienił się nasz ustrój: gospodarka (bez tego cofalibyśmy się w stosunku do Zachodu), media, społeczeństwo obywatelskie. Wydaje mi się, że najmniej zmian mamy w tych dziedzinach, w których potrzebne były tylko przekształcenia, ponieważ nie dało się ich likwidować, tzn. w prokuraturze i sądach. Mam tu na myśli dwie rzeczy: efektywność - co jest prostsze, choć też trafia na opory, i o rzecz z moralnego punktu widzenia jeszcze istotniejsza, a mianowicie: zmniejszenie odsetka ludzi niewinnych ściganych (to jest bardziej drastyczne niż nieściganie winnych). I żeby osiągnąć postęp w tej dziedzinie, jest potrzebna, jak zawsze, daleko większa, bardziej systematyczna mobilizacja fachowych kręgów - oczywiście myślę tu też o prawnikach, ale i opinii publicznej. 


\section{POLISH ADMINISTRATION OF JUSTICE FROM THE POINT OF VIEW OF INSTITUTIONAL ECONOMY}

\section{Summary}

This paper contains general characteristics of a regime (being an institutional system) and a discussion on the specificity of socialism as a type of regime and its repressiveness. It also presents the type of institutional changes implemented after socialism and, in particular, in the wording of the laws and the system of types of organisation. Against this background, institutional factors fundamental for economy are analysed, and two main aspects of law enforcement and administration of justice: the (in)effectiveness and (in)justice are discussed with a special focus on Poland's reality. 
Copyright of Journal of Law, Economics and Sociology is the property of Faculty of Law and Administration of Adam Mickiewicz University in Poznan and its content may not be copied or emailed to multiple sites or posted to a listserv without the copyright holder's express written permission. However, users may print, download, or email articles for individual use.

Właścicielem praw autorskich do „Ruchu Prawniczego, Ekonomicznego i Socjologicznego” jest Wydział Prawa i Administracji Uniwersytetu im. Adama Mickiewicza w Poznaniu. Zawartość czasopisma nie może być kopiowana, przesyłana do innych stron internetowych bądź zamieszczana na blogach bez pisemnej zgody wydawcy. Niemniej artykuły można drukować, kopiować lub przesyłać w formie elektronicznej na własny użytek. 